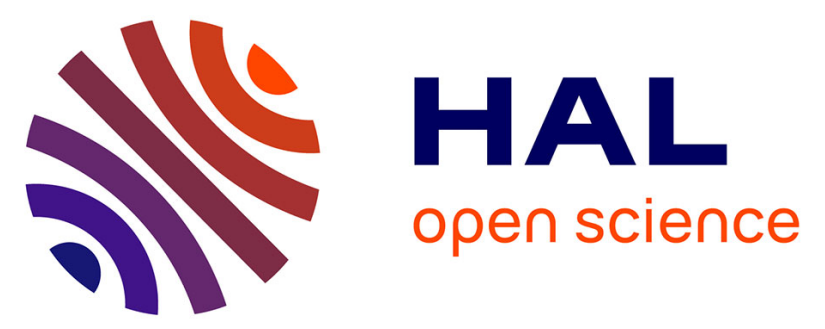

\title{
First record of Sivameryx (Cetartiodactyla, Anthracotheriidae) from the lower Miocene of Israel highlights the importance of the Levantine Corridor as a dispersal route between Eurasia and Africa
} Ari Grossman, Ran Calvo, Raquel López-Antoñanzas, Fabien Knoll, Gideon Hartman, Rivka Rabinovich

\section{To cite this version:}

Ari Grossman, Ran Calvo, Raquel López-Antoñanzas, Fabien Knoll, Gideon Hartman, et al.. First record of Sivameryx (Cetartiodactyla, Anthracotheriidae) from the lower Miocene of Israel highlights the importance of the Levantine Corridor as a dispersal route between Eurasia and Africa. Journal of Vertebrate Paleontology, 2019, 39 (2), pp.e1599901. 10.1080/02724634.2019.1599901 . hal-02365607

\section{HAL Id: hal-02365607 https://hal.science/hal-02365607}

Submitted on 16 Dec 2020

HAL is a multi-disciplinary open access archive for the deposit and dissemination of scientific research documents, whether they are published or not. The documents may come from teaching and research institutions in France or abroad, or from public or private research centers.
L'archive ouverte pluridisciplinaire HAL, est destinée au dépôt et à la diffusion de documents scientifiques de niveau recherche, publiés ou non, émanant des établissements d'enseignement et de recherche français ou étrangers, des laboratoires publics ou privés. 


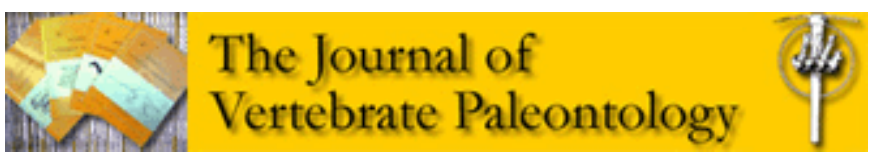

\section{First description of Sivameryx (Cetartiodactyla: Anthracotheriidae) from the Early Miocene of Israel highlights the importance of the Levantine Corridor as a dispersal route between Eurasia and Africa}

\begin{tabular}{|r|l|}
\hline Journal: & Journal of Vertebrate Paleontology \\
\hline Manuscript ID & JVP-2018-0083.R3 \\
\hline Danuscript Type: & Article \\
\hline Author: & 11 -Mar-2019 \\
\hline Complete List of Authors: & $\begin{array}{l}\text { Grossman, Aryeh; Midwestern University, Anatomy; Midwestern } \\
\text { University, College of Veterinary Medicine; Midwestern University, } \\
\text { Arizona College of Osteopathic Medicine } \\
\text { Calvo, Ran; Geological Survey of Israel } \\
\text { López-Antoñanzas, Raquel; Institut des Sciences de I'Evolution de } \\
\text { Montpellier, Université Montpellier, CNRS, IRD, EPHE. } \\
\text { Knoll, Fabien; Fundación Conjunto Paleontológico de Teruel-Dinópolis, ; } \\
\text { University of Manchester, School of Earth \& Environmental Sciences, } \\
\text { Hartman, Gideon; University of Connecticut, Anthropology } \\
\text { Rabinovich, Rivka; The Hebrew University of Jerusalem, National Natural } \\
\text { History Collections, Institute of Earth Sciences, Institute of Archaeology, }\end{array}$ \\
\hline Key Words: & $\begin{array}{l}\text { Israel, early Miocene, anthracotheriidae, cetartiodactyla, } \\
\text { <i>Sivameryx</i>, Levantine corridor }\end{array}$ \\
\hline
\end{tabular}

\section{SCHOLARONE ${ }^{\mathrm{m}}$ Manuscripts}


1 First description of Sivameryx (Cetartiodactyla, Anthracotheriidae) from the Early Miocene of

2 Israel highlights the importance of the Levantine Corridor as a dispersal route between Eurasia and Africa

4 ARI GROSSMAN, * ,1,2,3 RAN CALVO, ${ }^{4}$ RAQUEL LOPEZ-ANTONANZAS, ${ }^{5}$ FABIEN KNOL, 6,7 GIDEON HARTMAN, ${ }^{8,9}$ and RIVKA RABINOVICH ${ }^{10}$

$6{ }^{1}$ Department of Anatomy, College of Graduate Studies, Midwestern University, Glendale, AZ

7 85308, USA, agross@midwestern.edu;

9 3Arizona College of Osteopathic Medicine, Midwestern University, Glendale, AZ 85308, USA;

115 Institut des Sciences de l'Évolution de Montpellier (ISE - M, UMR 5554, CNRS/UM/IRD/EPHE),

12 c.c. 64, Université de Montpellier, Place Eugène Bataillon, F -34095 Montpellier Cedex 05, France; ${ }^{6}$ ARAID—Fundación Conjunto Paleontológico de Teruel-Dinopolis, 44002, Teruel, Spain; United Kingdom; Storrs, CT 06269, USA;

\footnotetext{
* Corresponding author
} 
$19{ }^{9}$ Center for Environmental Sciences and Engineering, University of Connecticut, 3107 Horsebarn

20 Hill Road, Building 4 room 10, Storrs, CT 06269, USA;

$21{ }^{10}$ National Natural History Collections, Institute of Earth Sciences, Institute of Archaeology, The 22 Hebrew University of Jerusalem, Berman Building, Edmond J. Safra Campus, Givat Ram, 23 Jerusalem 91904, Israel 24

25 RH: GROSSMAN ET AL. - FIRST ANTHRACOTHERE FROM ISRAEL

26 
27 ABSTRACT - The genus Sivameryx (Cetartiodactyla: Anthracotheriidae), found both in Asia and 28 Africa, is considered of Asian origin. Recent excavations in the Negev region of southern Israel 29 led to the discovery of a new Early Miocene site called Kamus Junction. Among the fossils 30 recovered at Kamus Junction is an upper molar of Sivameryx palaeindicus. Although known 31 species of Sivameryx have often been distinguished by size, comparisons of the new specimen

32 with known Sivameryx teeth from Asia and Africa emphasize the need for caution when

33 assigning Sivameryx fossils to species based on size alone. This record of Sivameryx highlights

34 the importance of the Levant as a corridor connecting Eurasia and Africa. The new find, along 35 with other recent finds, demonstrates that the Levantine Corridor facilitated faunal dispersal 36 events that shaped modern biotas as early as the Early Miocene.

INTRODUCTION

Multiple mammalian orders and families appear to have migrated from Africa to Eurasia

41 during the Early and Middle Miocene in a series of relatively rapid migration events (e.g. Cote et

42 al., 2018; Leakey et al., 2011). An uncertain but substantial number of African taxa such as

43 proboscideans migrated out of Africa roughly simultaneously (e.g. Sanders et al., 2010; Sanders

44 and Miller, 2002). Direct fossil evidence for these migrations from sites that lie between Africa

45 and Eurasia are rare but crucial for reconstructing biogeographic patterns of dispersal. The

46 Levantine Corridor, located between Africa and Eurasia, provides the best case for studying

47 such patterns (Tchernov et al., 1987). Preliminary descriptions recognized 19 fossil Early 
48 Miocene mammal taxa from the Negev of Israel (Goldsmith et al., 1982; Savage and Tchernov,

49 1968; Tchernov et al., 1987). These taxa were primarily of African affinities but demonstrated

50 high levels of regional endemism, which, the authors argued, were probably indicative of

51 environmental and not temporal differences with other sites in Africa and Asia (Tchernov et al., 52 1987).

53 Anthracotheres are relatively common in the Early Miocene fossil record of East and

54 North Africa (Evans et al., 1981; Leakey et al., 2011; Rowan et al., 2015) as well as Eurasia

55 (Antoine et al., 2013; Ducrocq and Lihoreau, 2006; Lihoreau and Ducrocq, 2007; Patnaik, 2013;

56 Savage et al., 1977; Sehgal and Bhandari, 2014). Because anthracotheres are so widely

57 dispersed, paleontologists often regard them as useful indicators of early phases of

58 intercontinental dispersal events (e.g. Lihoreau and Ducroq, 1995; Holroyd et al., 2010).

59 Anthracotheres appear in the early reports of mammals from the Miocene of Israel (Goldsmith

60 et al., 1982; Savage and Tchernov, 1968), and Goldmsith even named the main Early Miocene

61 locality from the Negev "Anthracothere Hill" (Goldsmith et al., 1988). However, the only formal

62 description of the Miocene mammals of the Negev in Israel, Tchernov et al. (1987: Table 7) does

63 not metion anthracotheres. Here we formally describe anthracothere remains from Israel for

64 the first time, specifically the material found at Kamus Junction.

65 In 2012, we began surveying and excavating new localities in Israel to reconstruct the

66 landscape and biota of the Levantine Corridor during the Miocene (López-Antoñanzas et al.,

67 2014; López-Antoñanzas et al., 2016; Rabinovich et al., 2014). During excavation of Kamus

68 Junction, a new Early Miocene locality, new specimens were recovered including 
69 proboscideans, a giraffid (Canthumeryx sp.), and one anthracothere tooth, which we describe

70 here.

71

72 Location and Geological Setting of Kamus Junction Locality

73

74

75

76

77

78

79

80

81

82

83

84

85

86

87

88

89

During the Early Miocene large drainage systems flowed from deep-inland areas of the Arabian Plate, in the southeast, toward the Neo-Tethys, in the northwest. The Hazeva Formation consists mostly of fluvial, fine to coarse, sandstones, with some shale and conglomerates. Episodically, lacustrine environments prevailed, and marls and limestone were also deposited (Calvo and Bartov, 2001). Remnants of the Miocene fluvial-lacustrine Hazeva Formation are preserved in the northern Negev in Israel in synclinal basins within the folds of the 'Syrian Arc' folds system (Zilberman and Calvo, 2013) (Fig. 1). Several large unconformities separate the members in the formation (Fig. 2). In the Yamin Plain, the upper parts of the Zefa Member coat the basin edge, and are covered by cycles of layers of the Rotem Member (Fig. 1C, E). The Rotem Member, with a thickness of up to $1,000 \mathrm{~m}$ in the Arava Valley, contains low- as well as highenergy alluvial facies represented by conglomerate-sand-silt-clay cycles. Due to unconformities, during- and post-Hazeva time, only $\sim 50 \mathrm{~m}$ of the Rotem Member are preserved in Yamin Plain. In 
90 KJ locality the lower part of the Rotem Member begins with $10 \mathrm{~m}$ of coarse sandstone layers with

91 cross-bedding, followed by $15 \mathrm{~m}$ of alternating sandstone and shale-marls layers (Fig. 1E). The

92 upper section begins with $1 \mathrm{~m}$ thick gritstone, which continues into friable sandstone with 93 petrified tree-trunks. HUJI KJ 31 was found eroding out of the sandstone along with fossils of 94 other mammals, crocodilians and turtles.

95

96 Age of Kamus Junction (KJ)

97 Due to the absence of radiometric dateable markers within the Hazeva Formation, only its 98 base and top ages are known. In central Sinai (Egypt) conglomerate of the base of the formation 99 overlay dikes of 25 Ma (K-Ar ages) (Steinitz et al., 1978), while in Jordan (east of the Yamin Plain) 100 a 20 Ma dike cuts the same stratigraphic unit (Calvo, 2000), indicating that the lower parts of 101 the Hazeva Formation were likely deposited during the late Oligocene or Early Miocene (Calvo 102 and Bartov, 2001). Based on geomorphological relationship between marine invasion and 103 terrestrial erosional episodes in Be'er Sheva area, Bar and Zilberman (2016) concluded that the 104 Hazeva Formation deposition ended before 16-14 Ma.

105

106 Dental terminology-mostly follows Boisserie et al. 2010 and Bärmann and Rössner. 2011.

107 
109

110 CETARTIODACTYLA Montgelard et al. 1997

111 ANTHRACOTHERIIDAE Leidy 1869

112 BOTHRIODONTINAE Scott, 1940

113 MERYCOPOTAMINI Lydekker, 1883

114 SIVAMERYX Lydekker, 1877

115 Type-species Sivameryx palaeindicus Lydekker, 1877

116 (included species: S. africanus Andrews 1914; S. moneyi Fourteau 1918)

117 Stratigraphic range: Early Miocene

118 Diagnosis-Following Pickford (1991); Lihoreau (2003), Holroyd et al. (2010), Lihoreau

119 et al. (2016). Medium to small in size; canines sexually dimorphic; p1 double rooted; lower

120 molars selenodont with anterior crests of labial cusps reaching lingual surface of crown, often

121 ending in a small cuspule; four crests from the metaconid; lingual cusps of lower molars

122 mediolaterally compressed; talonid of m3 loop-like and strongly obliquely oriented; upper

123 molars with four main cusps and a paraconule almost fused with protocone and of similar

124 height (=quasi-pentacuspidate); looplike parastyles and mesostyles; two distal crests from

125 protocone; symphysis reaches back to level of p1; no genial spine; postcanine diastema long,

126 with a flange-like protuberance leaning laterally; enamel microstructure is a mono-zonal radial

127 Schmelzmuster (not equivalent to the cetartiodactyl plesiomorph condition). 


\section{New Material-HUJI KJ 31: Right second molar (M2) (Fig. 2)}

Comparative Description - the tooth is a nearly complete crown with a slightly broken anterior (=mesial) cingulum and the anterior part of the roots also sheared. The molar is bucco-

131 lingually $(21.8 \mathrm{~mm})$ wider than it is mesio-distally long $(19.8 \mathrm{~mm})$. The crown is brachyodont and 132 the cusps are selenodont and high, giving the crown a tall appearance. There are four main 133 cusps (paracone, protocone, metacone, metaconule), and a fifth very small paraconule, a 134 distinctive character of Sivameryx referred to as quasi-pentacuspidate by some authors 135 (Holroyd et al., 2010; Pickford, 1991). The tips of the metacone and the paracone of HUJI KJ 31 136 pinch-in so that the tips of the cusps are close together. This pinching exaggerates the sloping 137 of the buccal sides of each buccal cusp contrasting with the less sloped lingual sides of the 138 lingual cusps. This is especially visible in the metacone. A looping mesostyle are connects the 139 two buccal cusps. The parastyle is partially broken but was clearly also looping and prominent.

140 The metastyle of HUJI KJ 31 is relatively smaller than the mesostyle or parastyle. The

141 preparacristule is broad but slightly abraded. It wraps around the mesiolingual side of the 142 paracone to merge with the parastyle. Both the metacone and the paracone have distinct 143 bulbous ribs descending buccally; that of the paracone appears larger although this could be an 144 artefact of the degree of erosion of the metacone. A median transverse valley separates the 145 mesial and distal portions of the toot. The narrow base of the valley is approximately at the 146 level of the cervix of the tooth. The median transverse valley is enclosed buccally by the 147 mesostyle, and continues lingually to terminate at the lingual cingulum. The mesial cingulum 148 begins at the mesial end of the parastyle where the preparacristule merges with the paracone. 149 The mesial cingulum is continuous with a very prominent and arcuate cingulum that surrounds 
150 the protocone lingually. This protocone cingulum merges with a second arcuate cingulum that

151 surrounds the metaconule, and the two cingula meet at the termination of the median

152 transverse valley. The metaconule cingulum is continuous with a distal cingulum that extends to

153 the distal part of the metastyle. Thus, the cingula form a single, shelf-like cingulum covering all

154 but the buccal aspect of the tooth.

HUJI KJ 31 shares with other bothriodontine anthracotheres an upper molar mesostyle

156 invaded by the median transverse valley and selenodont crescenteric cusps. Anthracotheriinae

157 differ by their accessory protostyle on the mesial cingulum, and relatively bunodont upper

158 molar cusps. Micorbunodontinae differ because they lack the median transverse valley invading

159 the mesostyle,

160 Members of the tribe Merycopotamini (Afromeryx, Sivameryx, Hemimeryx,

161 Merycopotamus, Libycosaurus) are distinguished in their upper molars from other

162 bothriodontine anthracotheres by a preparacrista that connects labially with the parastyle, lack

163 of ectocristyle, and development of the molar entostyle (Lihoreau et al., 2016). All characters

164 observed in HUJI KJ 31. We thus restrict further comparisons primarily to Merycopotamini with

165 a few additions.

166 We place HUJ KJ 31 in Sivameryx because it is a five-cusped upper molar with a reduced 167 paraconule (i.e. quasi-pentascuspidate). It also shares with Sivameryx a loop-like mesostyle and 168 a strongly developed lingual cingulum of the protocone. 

Brachyodus (Early Miocene of Africa and Europe, Middle Miocene of Thailand) differs

170 from HUJI KJ 31 because it has pinched rather than looping styles on its upper molars.

171 Brachyodus is also much bigger than HUJI KJ 31.

173 Early Miocene of Pakistan), Telmatodon (Early Miocene of Palistan), Gonotelma ( Libycosaurus

174 (Late Miocene of North Africa and Uganda), and Merycompotamus (late Middle Miocene to

175 Late Miocene of India and Pakistan) differ from HUJI KJ 31 because they are tetracuspidate and 176 their upper molars lack a paraconule.

178 distribution differs from HUJI KJ 31, by its much more developed paraconule, which is located 179 substantially farther from the protocone than seen in Sivameryx.

We recognize HUJI KJ 31 as a second upper molar (M2). The tooth has a distal wear

181 facet indicating that it is not an M3. Furthermore, the marked pinching of the tips of the

182 metacone and the paracone causing exaggerated sloping of the buccal sides of each buccal cusp

183 is particularly exaggerated on the metacone of HUJI KJ 31, a condition typically more marked on

$184 \mathrm{M} 1$ and M2. To determine if it is a first or second upper molar, we collected all available mesio-

185 distal length and bucco-lingual width measurements of upper molars assigned to Sivameryx

186 (Table 1). We used a simple bi-variate plot to compare HUJI KJ 31 with the other upper molars

187 belonging to Sivameryx species (Fig. 3). Recent discoveries of skulls of S. africanus (Rowan et al.,

188 2015) and S. moneyi (Miller et al., 2014) demonstrate that in both S. africanus and S. moneyi

189 the $\mathrm{M} 1$ is smaller than $\mathrm{M} 2$ and $\mathrm{M} 3$. The $\mathrm{M} 2$ and $\mathrm{M} 3$ overlap in size although the M3 is generally 
190 larger than M2 (Fig. 3). HUJI KJ 31 falls within the cluster that includes M2 of S. africanus, S. 191 moneyi, and S. palaeindicus (Fig. 3), and thus we recognize it as an M2.

\section{DISCUSSION}

Four Early Miocene genera of anthracotheres are known from Africa: Brachyodus,

195 Sivameryx, Afromeryx, and Jaggermeryx. The distribution of the species of these genera

196 suggests that African anthracotheres dispersed from Africa to Eurasia, while Eurasian

197 anthracotheres dispersed to Africa. However, the exact pathways enabling such dispersals are

198 unknown. Jaggermeryx naida is a monospecific genus identified only from dentaries and lower

199 dentition found at Wadi Moghra in Egypt (Miller et al., 2014). As such, direct comparisons with

200 HUJI KJ 31 are impossible. However, J. naida differs from known lower dentition of Sivameryx

201 by its bunodont rather than selenodont dentition and overall greater size (Miller et al., 2014). J.

202 naida is an African genus. Miller et al. (2014) suggested that this genus is derived from older

203 African anthracotheres found in Oligocene deposits of the Fayum in Egypt.

204 Brachyodus is considered a descendant of Bothriogenys from the Oligocene of the 205 Fayum in Egypt and thus of African origin (Holroyd et al., 2010). Brachyodus currently includes 206 three species in Africa; B. depreteti from Wadi Moghara and Siwa in Egypt (Miller et al., 2014; 207 Pickford, 1991), and from Sperrgebiet in Namibia (Pickford, 2008); B. mogharensis found only at 208 Wadi Moghra (Miller et al., 2014; Pickford, 1991); and B. aequatorialis in various localities in 209 East Africa (Kalodirr, Rusinga, Loperot, and Locherangan, Kenya, and Moroto, Uganda) (Holroyd 210 et al., 2010). Records of Brachyodus in Eurasia include: B. onoideus from Early Miocene deposits 
211 in southern Europe (Portugal, Spain, France; (e.g. Antunes and Ginsburg, 2010; Orliac et al.,

212 2013) and from Middle Miocene deposits in Thailand (Ducroq et al., 2003). The exact pathway

213 and timing of the dispersal by Brachyodus from Africa into Eurasia is as yet undetermined.

214 Afromeryx zelteni is recognized in North Africa (Jebel Zelten, Libya), East Africa (Loperot, 215 Buluk, Ombo, Nachola and Wayondo, Kenya), and in Ghaba, Sultanate of Oman (Holroyd et al., 216 2010; Pickford, 1991; Thomas et al., 1999). A second species A. africanus is known only from 217 Jebel Zelten in Libya. Two new species A. grex and A. palustris were recently described from 218 Wadi Moghara (Miller et al., 2014). No records of Afromeryx are known from Eurasia. Although 219 there is disagreement about its exact ancestral relationsips (e.g. Pickford, 1991 vs. Lihoreau and 220 Ducroq, 2007), some researchers argue that it is of Eurasian origin (Holroyd et al., 2010; 221 Lihoreau and Ducroq, 2007; Pickford, 1991). Three species, one Asian and two African, are currently included in the genus Sivameryx.

223 The type species S. palaeindicus, known from several sites in India and Pakistan, is similar in size 224 and morphology to S. africanus, found in East and North Africa (e.g. Holroyd et al., 2010; 225 Lihoreau and Ducrocq, 2007). While some prefer to retain them as two geographically distinct 226 species (Holroyd et al., 2010), others suggest that there is insufficient morphological evidence 227 to distinguish between the two species and the earlier name Sivameryx palaeindicus should 228 take precedence (Lihoreau and Ducrocq, 2007). In addition to Sivameryx africanus identified in 229 East Africa (Karungu, Rusinga, Chianda Uyoma, Kalodirr, Holroyd et al., 2010; Pickford, 1991;

230 Rowan et al., 2015), and North Africa (Gebel Zelten, Pickford, 1991), and possibly in Tunisia 231 (Oued Bazina, (Lihoreau, 2003), the third species, S. moneyi, is known only from Wadi Moghara 
232 in Egypt (Holroyd et al., 2010; Miller et al., 2014). The two African species are regarded as

233 morphologically indistinct and are only separated by size differences expressed in the length of

234 the mandibular molar row ( $\sim 80 \mathrm{~mm}$ in S. africanus vs. $\sim 59 \mathrm{~mm}$ in S. moneyi) (Pickford, 1991).

235 Sivameryx africanus and S. moneyi are considered migrants from Eurasia to Africa (Holroyd et

236 al., 2010; Lihoreau and Ducroq, 2007; Miller et al., 2014; Pickford, 1991).

237 In order to assign HUJI KJ 31 to a species we wanted to determine if it is similar in size to

238 S. moneyi from Wadi Moghra or the larger species S. palaeindicus and S. africanus. HUJI KJ 31 is

239 an upper molar, but we expect that the maxillary molars will mirror differences in the size of

240 mandibular molars. However, our analysis of the upper molar dimensions of Sivameryx from

241 Asia, East Africa, and North Africa (Fig. 3) does not support such size distinction. In our analysis,

242 the smallest individuals are specimens assigned to S. africanus from Kalodirr (Holroyd et al.,

243 2010; Rowan et al., 2015). At the same time, the S. moneyi specimens from Wadi Moghara have

244 a size range as great as the range of upper molars from India, Pakistan, or Gebel Zelten,

245 attributed to either S. palaeindicus or S. africanus (Fig. 3). Alternatively, the overlap in size of

246 the upper molars of S. moneyi, S. africanus, and S. palaeindicus combined with very little

247 morphological variation may indicate that Sivameryx is a monospecific genus. A complete

248 phylogenetic analysis required to examine this alternative is outside the scope of this paper. We

249 suggest that size alone, at least as expressed via molar size, is not sufficient to distinguish

250 different species of Sivameryx without additional material from well-dated localities. We

251 therefore assign the specimen from Israel as S. palaeindicus because we cannot separate any of

252 the species by upper molar size or morphology and the name S. palaeindicus takes precedence

253 in the literature. 
254 Regardless whether the genus Sivameryx has one or three species, all authors agree that 255 the genus is an Asian immigrant into Africa (Holroyd et al., 2010; Lihoreau and Ducrocq, 2007;

256 Miller et al., 2014; Pickford, 1991; Rowan et al., 2015). HUJI KJ 31 is found in the Levantine 257 Corridor, an area that physically connects the two continents. This discovery of Sivameryx in 258 Israel is part of a growing body of evidence (e.g. ctenodactylid rodents: López-Antoñanzas et al., 259 2016) that mammals exploited this route to migrate between Asia and Africa as early as the 260 Early Miocene.

261

ACKNOWLEDGMENTS

263

264 This research is supported by ISF Grant \#925/16 (RR and RC). AG is supported by a grant from

265 Midwestern University. We are very grateful to the two anonymous reviewers for their

266 thorough and helpful comments and comments from the editor, Dr. M. Sanchez-Villagra, which

267 greatly improved the final manuscript. We wish to thank G. Beiner for preparing the material

268 and V. Gutkin for SEM of the specimen. The faunal collection is deposited at the National

269 Natural History Collection of the Hebrew University of Jerusalem. 
273 Andrews, C. W. 1914. On the Lower Miocene Vertebrates from British East Africa, collected by Dr. Felix 274 Oswald. Quarterly Journal of the Geological Society 70:163-186.

275 Antoine, P.-O., G. Métais, M. J. Orliac, J. Crochet, L. J. Flynn, L. Marivaux, A. R. Rajpar, G. Roohi, and J.-L. 276 Welcomme. 2013. Mammalian Neogene biostratigraphy of the Sulaiman Province, Pakistan. 277 Fossil mammals of Asia: Neogene Biostratigraphy and Chronology. Columbia University Press, 278 New York:400 - 422 .

Antunes, M. T., and L. Ginsburg. 2010. The last Anthracothere Brachyodus onoideus (Mammalia, Artiodactyla) from westernmost Europe and its extinction.

Bar, O., and E. Zilberman. 2016. Subsidence and conversion of the Dead Sea basin to an inland erosion base level in the early middle Miocene as inferred from geomorphological analysis of its ancient western fluvial outlet. Geomorphology 261:147 - 161.

Bärmann, E. V., and G. E. Rössner. 2011. Dental nomenclature in Ruminantia: Towards a standard terminological framework. Mammalian Biology 76:762-768.

Boisserie, J.-R., F. Lihoreau, M. Orliac, R. E. Fisher, E. M. Weston, and S. Ducrocq. 2010. Morphology and phylogenetic relationships of the earliest known hippopotamids (Cetartiodactyla, Hippopotamidae, Kenyapotaminae). Zoological Journal of the Linnean Society 158:325-366.

Calvo, R. 2000. Stratigraphy and petrology of the Hazeva Formation in the Arava and the Negev: Implications for the development of the sedimentary basins and the morphotectonics of the Dead Sea Rift Valley: In Geology, Vol. PhD, pp. 113 (in Hebrew, with English abstract). The Hebrew University in Jerusalem.

Calvo, R., and Y. Bartov. 2001. Hazeva Group, southern Israel: New observations, and their implications for its stratigraphy, paleogeography, and tectono-sedimentary regime. Israel Journal of Earth Sciences 50:71-99. 
296 Cote, S., J. Kingston, A. Deino, A. Winkler, R. Kityo, and L. MacLatchy. 2018. Evidence for rapid faunal 297 change in the early Miocene of East Africa based on revised biostratigraphic and radiometric 298 dating of Bukwa, Uganda. Journal of Human Evolution 116:95 - 107.

299 Ducrocq, S., Y. Chaimanee, V. Suteethorn, and J.-J. Jaeger. 2003. Occurrence of the anthracotheriid 300 Brachyodus (Artiodactyla, Mammalia) in the early Middle Miocene of Thailand. Comptes Rendus Palevol 2:261-268.

Ducrocq, S., and F. Lihoreau. 2006. The occurrence of bothriodontines (Artiodactyla, Mammalia) in the 303 Paleogene of Asia with special reference to Elomeryx: Paleobiogeographical implications. Journal of Asian Earth Sciences 27:885 - 891.

Evans, E. N., J. A. Van Couvering, and P. Andrews. 1981. Palaeoecology of Miocene sites in western 306 Kenya. Journal of Human Evolution 10:99 - 116.

307 Fourteau, R. 1918. Contribution a l'etude des vertebres miocenes de l'Egypte. Geological Survey Department, Ministry of Finance, Egypt, Cairo. 120p.

Goldsmith, N., E. Tchernov, L. Ginsburg, P. Tassy, and J. Van Couvering. 1982. Ctenodactylid rodents in the Miocene Negev fauna of Israel. Nature 296:645 - 647.

Goldsmith, N. F., F. Hirsch, G. M. Friedman, E. Tchernov, B. Derin, E. Gerry, A. Horowitz, and G. Weinberger. 1988. Rotem mammals and Yeroham crassostreids: stratigraphy of the Hazeva Formation (Israel) and the paleogeography of Miocene Africa. Newsletters on Stratigraphy:73 90.

Gvirtzman, G., and B. Buchbinder. 1969. Outcrops of Neogene Formation in the Central and Southern Coastal Plain, Hashephela and Beer Sheva'Regions, Israel. Geological Survey of Israel Bulletin

318 Holroyd, P., F. Lihoreau, G. Gunnell, E. Miller, L. Werdelin, and W. Sanders. 2010. Anthracotheriidae. Cenozoic Mammals of Africa. University of California Press, Berkeley:843 - 851. 
320 Leakey, M., A. Grossman, M. Gutiérrez, and J. G. Fleagle. 2011. Faunal change in the Turkana Basin 321 322 during the late Oligocene and Miocene. Evolutionary Anthropology: Issues, News, and Reviews $20: 238-253$.

Leidy, J. 1869. The extinct mammalian fauna of Dakota and Nebraska including an account of some allied forms from other localities, together with a synopsis of the mammalian remains of North America. Journal of the Academy of Natural Sciences of Philadelphia, series 2 7:1-472.

Lihoreau, F. 2003. Systématique et paléoécologie des Anthracotheriidae [Artiodactyla; Suiformes] du mio-pliocène de l'ancien monde: implications paléobiogéographiques. Ph.D. Thesis, Université de Poitiers, Poitiers, France, 395pp.

Lihoreau, F., L. Alloing-Séguier, P.-O. Antoine, J.-R. Boisserie, L. Marivaux, G. Métais, and J.-L. Welcomme. 2016. Enamel microstructure defines a major Paleogene hippopotamoid clade: the Merycopotamini (Cetartiodactyla, Hippopotamoidea). Historical Biology:1 - 11.

Lihoreau, F., and S. Ducrocq. 2007. Family Anthracotheriidae; pp. $89-105$ in D. R. Prothero, and S. E. Foss (eds.), The evolution of artiodactyls. The Johns Hopkins University Press, Baltimore, MD.

López-Antoñanzas, R., V. Gutkin, R. Rabinovich, R. Calvo, and A. Grossman. 2014. The rodent fauna from the Early Miocene of the Rotem Basin (Israel): African, Asian, both or neither. Journal of Vertebrate Paleontology 34 (suppl.),:170.

López-Antoñanzas, R., V. Gutkin, R. Rabinovich, R. Calvo, and A. Grossman. 2016. A Transitional Gundi (Rodentia: Ctenodactylidae) from the Miocene of Israel. PLoS One 11:e0151804.

Lydekker, R. 1877. Notices of new and rare Mammals from the Siwaliks. Records of the geological Survey of India 10:76-83.

Miller, E. R., G. F. Gunnell, M. A. Gawad, M. Hamdan, A. N. El-Barkooky, M. T. Clementz, and S. M. Hassan. 2014. Anthracotheres from Wadi Moghra, early Miocene, Egypt. Journal of Paleontology $88: 967-981$. 
344 Montgelard, C., F. M. Catzeflis, and E. Douzery. 1997. Phylogenetic relationships of artiodactyls and 345 cetaceans as deduced from the comparison of cytochrome $b$ and 125 rRNA mitochondrial sequences. Molecular Biology and Evolution 14:550-559.

347 Orliac, M. J., P.-O. Antoine, A.-L. Charruault, S. Hervet, F. Prodeo, and F. Duranthon. 2013. Specialization 348 for amphibiosis in Brachyodus onoideus (Artiodactyla, Hippopotamoidea) from the Early 349 Miocene of France. Swiss Journal of Geosciences 106:265-278.

Patnaik, R. 2013. Indian Neogene Siwalik mammalian biostratigraphy: an overview. Fossil mammals of Asia: Neogene Biostratigraphy and Chronology. Columbia University Press, New York:423 - 444.

Pickford, M. 1991. Revision of the Neogene Anthracotheriidae of Africa. The Geology of Libya:1491 1525.

Pickford, M. 2008. Anthracotheriidae from the Early Miocene deposits of the northern Sperrgebiet, Namibia. Geology and palaeobiology of the Northern Sperrgebiet, Namibia. Geological Survey of Namibia, Memoir 20:343-348.

Rabinovich, R., A. Grossman, H. Ginat, Y. Avni, and R. Calvo. 2014. Newly discovered Miocene proboscideans in the southern Levant. Journal of Vertebrate Paleontology 34 (suppl.),:210.

Rowan, J., B. Adrian, and A. Grossman. 2015. The first skull of Sivameryx africanus (Anthracotheriidae, Bothriodontinae) from the early Miocene of East Africa. Journal of Vertebrate Paleontology 35:3

362 Sanders, W. j., E. Gheerbrant, J. M. Harris, H. Saegusa, and C. Delmer. 2010. Proboscidea; pp. $161-251$ e928305.

365 Sanders, W. J., and E. R. Miller. 2002. New proboscideans from the early Miocene of Wadi Moghara, Egypt. Journal of Vertebrate Paleontology 22:388-404.

367 Savage, R., and E. Tchernov. 1968. Miocene mammals of Israel. Proc Geol Soc London 1648:98 - 101. 
368 Savage, R. J., P. C. Dixit, and D. Murty. 1977. On an anthracothere upper molar from Ladakh, Kashmir. 369 Journal of the Palaeontological Society of India 20:219 - 223.

370 Sehgal, R., and A. Bhandari. 2014. Miocene mammals from India: present status and future prospects. 371 Indian Miocene: a geodynamic and chronological framework for palaeobiota, sedimentary 372 environments and palaeoclimates. Palaeontol. Soc. India Spec. Publ 5:199 - 212.

373 Steinitz, G., Y. Bartov, and J. Hunziker. 1978. K-Ar age determinations of some Miocene-Pliocene basalts 374 in Israel: their significance to the tectonics of the Rift Valley. Geological Magazine 115:329 - 340.

375 Tchernov, E., L. Ginsburg, P. Tassy, and N. Goldsmith. 1987. Miocene mammals of the Negev (Israel). $376 \quad$ Journal of Vertebrate Paleontology 7:284-310.

377 Thomas, H., R. Jack, S. Sen, M. Pickford, E. Gheerbrant, Z. Al-Sulaimani, and S. Al-Busaidi. 1999.

378 Oligocene and Miocene terrestrial vertebrates in the Southern Arabian peninsula (Sultanate of 379 Oman) and their geodynamic and paleogeographic settings; pp. 430-442 in P. J. Whybrow, and 380 A. Hill (eds.), Fossil vertebrates of Arabia. Yale University Press, New Haven, CT.

381 Zilberman, E., and R. Calvo. 2013. Remnants of Miocene fluvial sediments in the Negev Desert, Israel, 382 and the Jordanian Plateau: Evidence for an extensive subsiding basin in the northwestern 383 margins of the Arabian plate. Journal of African Earth Sciences 82:33 - 53.

385 Submitted July 14, 2018; accepted Month DD, YYYY 
392 FIGURE 1. Location map of the Kamus Junction (KJ) locality in the Yamin Plain, northern Negev, 393 Israel.

394 A. General location of northern Negev, Israel.

395 B. Hazeva Formation outcrops in the northern Negev. Kamus Junction area is marked by a $396 \quad$ blue star.

C. The Hazeva Formation fills the Yamin Plain with all of its members. In the Kamus Junction area the upper parts of Zefa Member are overlain by clastic units of the Rotem Member. Small unconformity separates the lower and upper parts of the Rotem Member. Green dot marks the location of the upper level of KJ site where HUJI KJ 31 was found.

D. Topographic elevation of KJ site where HUJI KJ 31 was found (Green dot).

E. Columnar stratigraphic section in the Kamus Junction locality. 
408

[Intended for $2 / 3$ page width]

409

410 FIGURE 3. Scatter plot of upper molars of Sivameryx spp.

411 KEY: Triangles $=$ M1, Squares $=$ M2, Trapezoid $=$ M3, Cross $=$ HUJ KJ 31

412 Grey fill = S. moneyi, Dark fill = S. africanus, White fill = S. palaeindicus

413 Measurements listed in Table 1

414

[Intended for 2/3 page width]

415

416 
TABLE 1. Measurements of Sivameryx spp. Upper molars

Specimen No. MD BL Tooth position Reference Site

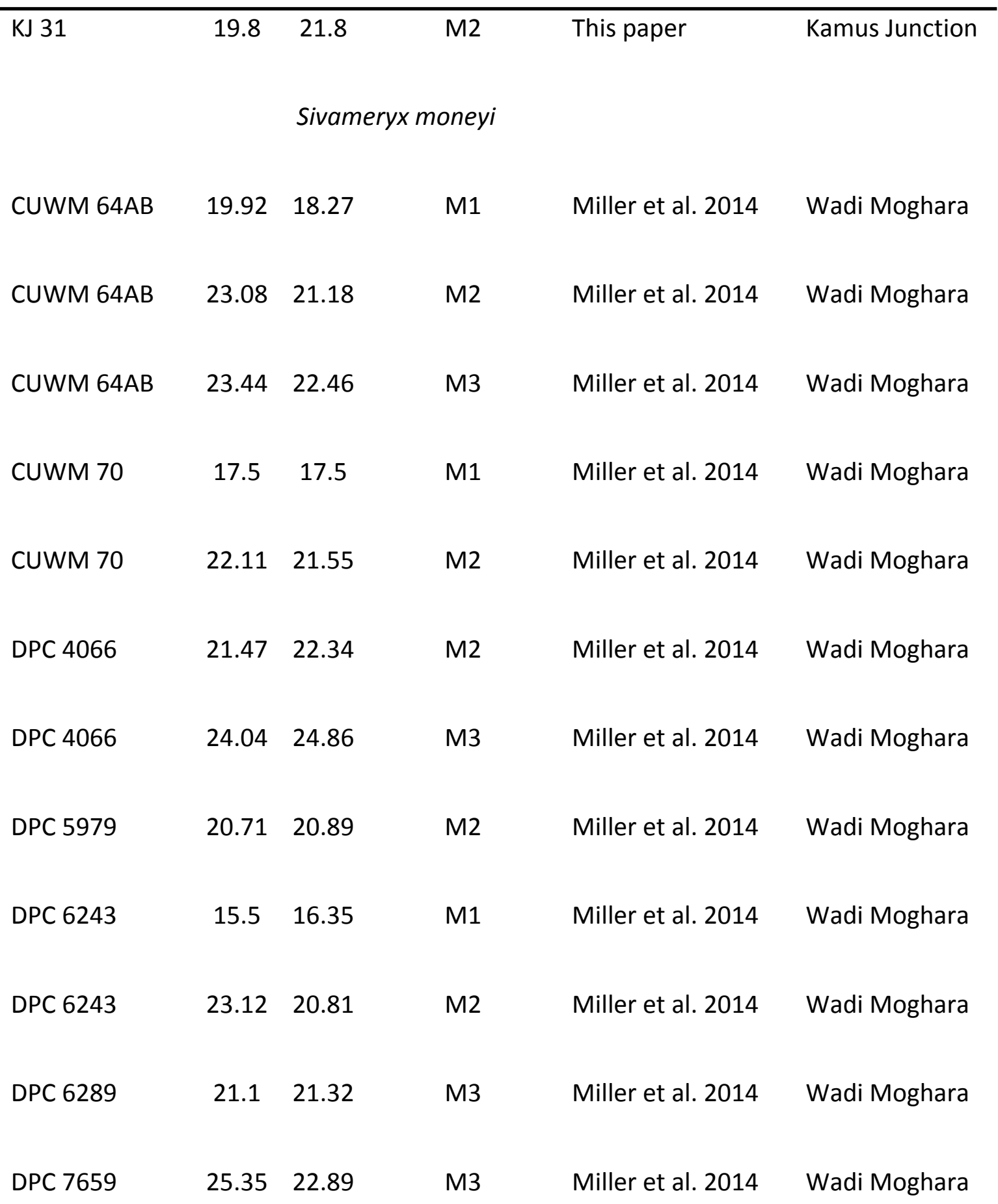


TABLE 1. (Continued)

$\begin{array}{lllllll}\text { DPC 17685 } & 20.69 & 20.08 & \text { M2 } & \text { Miller et al. 2014 } & \text { Wadi Moghara } \\ \text { DPC 17685 } & 22.23 & 22.12 & \text { M3 } & \text { Miller et al. 2014 } & \text { Wadi Moghara } \\ \text { DPC 21506 } & 27.49 & 30.03 & \text { M3 } & \text { Miller et al. } 2014 & \text { Wadi Moghara }\end{array}$

Sivameryx africanus

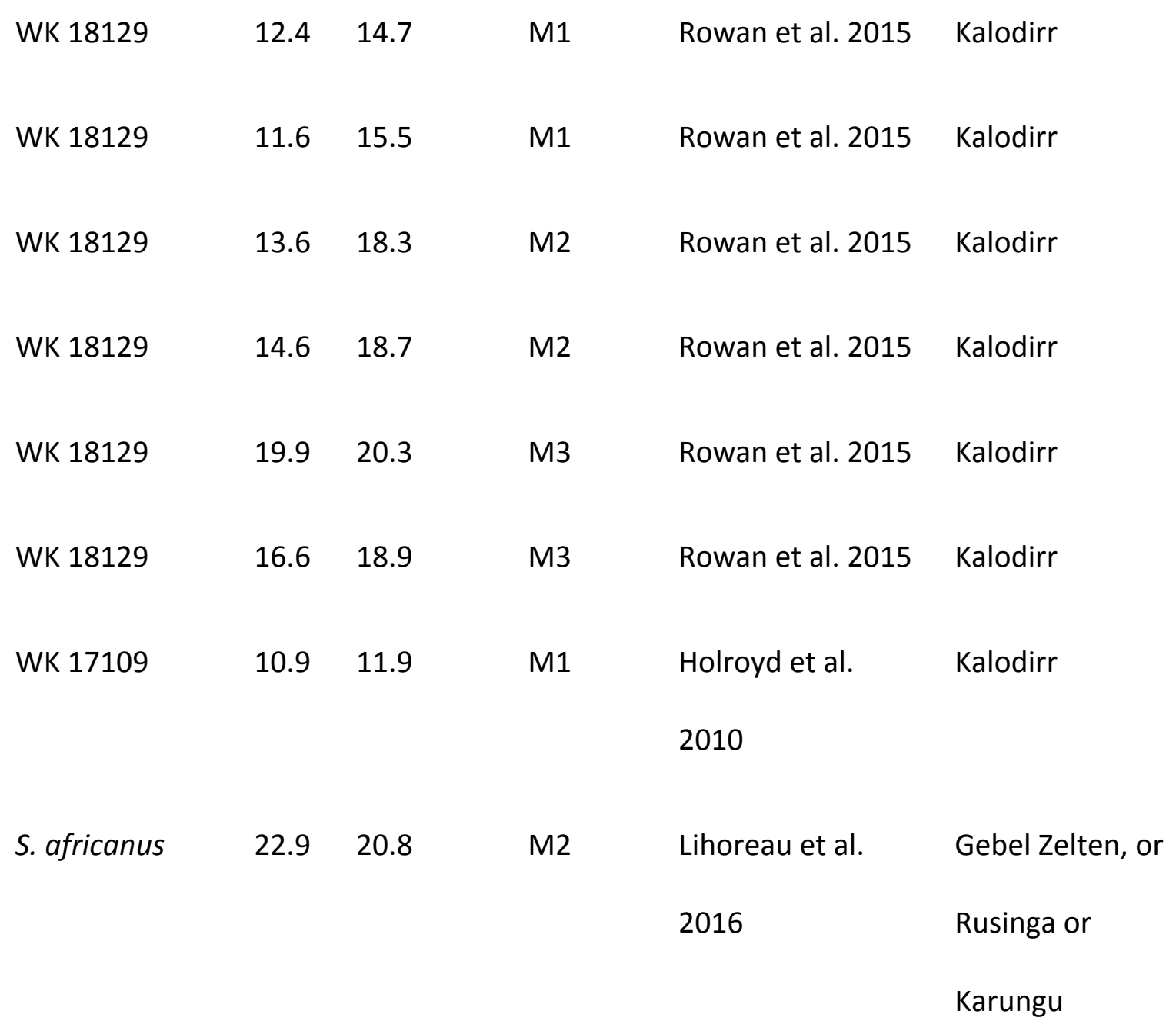

Sivameryx palaeindicus 


\begin{tabular}{|c|c|c|c|c|c|}
\hline Ladakh Molar & 24 & 26 & M2 & Savage et al. 1977 & Ladakh \\
\hline B82 & 22 & 25 & ?M3 & Savage et al. 1977 & Laki Hills \\
\hline B82 & 20.5 & 22.5 & ?M2 & Savage et al. 1977 & Laki Hills \\
\hline \multicolumn{6}{|c|}{ TABLE 1. (Continued) } \\
\hline M12738 & 24 & 25 & M3 & Savage et al. 1977 & Dera Bugti \\
\hline B482 & 19 & 20 & ?M1 & Savage et al. 1977 & Bugti Hills \\
\hline B482a & 21 & 22.5 & ?M2 & Savage et al. 1977 & Bugti Hills \\
\hline Y238 & 19 & 18 & M1 & Lihoreau 2003 & Potwar Y27926 \\
\hline
\end{tabular}

10

11

12

13

14

15

16

17

18

19

20

21

22

23

24

25

26

27

28

29

30

31

32

33

34

35

36

37

38

39

40

41

42

43

44

45

46

47

48

49

50

51

52

53

54

55

56

57

58

59

60 


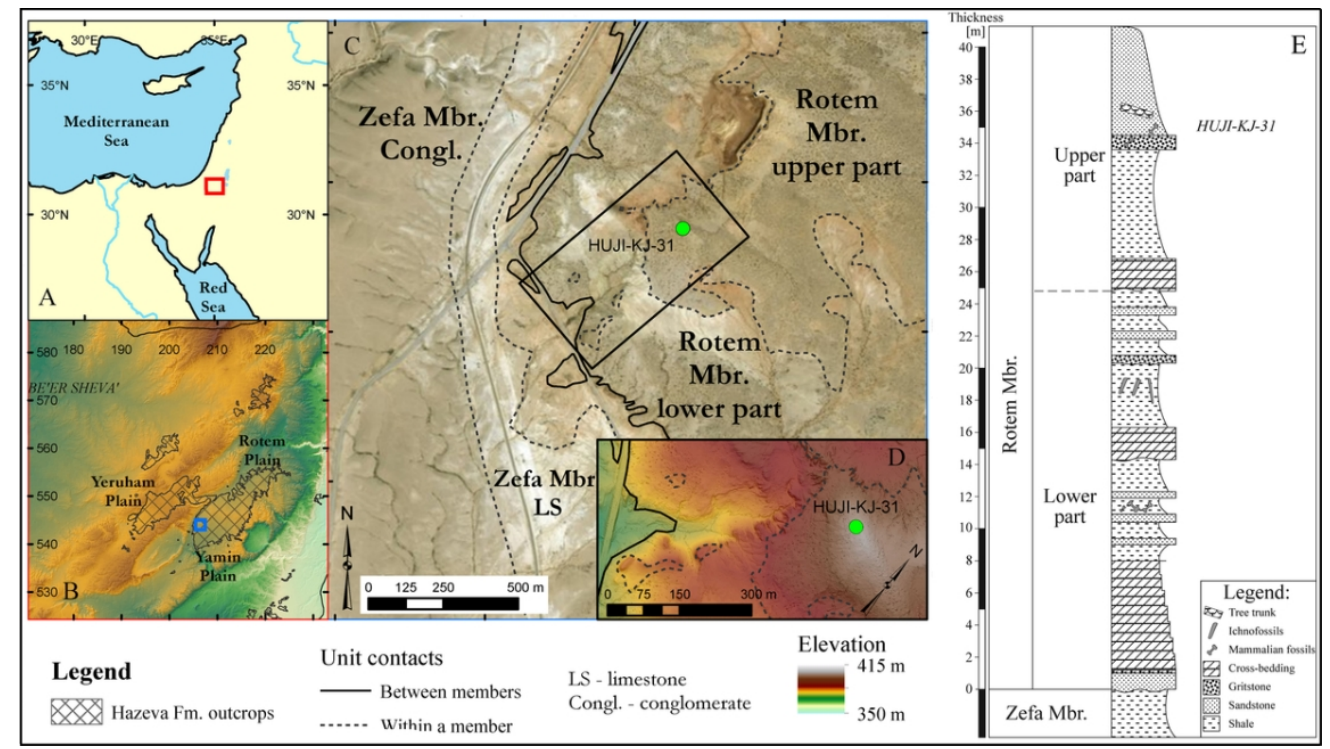

FIGURE 1. Location map of the Kamus Junction (KJ) locality in the Yamin Plain, northern Negev, Israel.

A. Genreal location of northern Negev, Israel.

B. Hazeva Formation outcrops in the northern Negev. Kamus Junction area is marked by a blue star.

C. The Hazeva Formation fills the Yamin Plain with all of its members. In the Kamus Junction area the upper parts of Zefa Member are overlain by clastic units of the Rotem Member. Small unconformity separates the lower and upper parts of the Rotem Member. Green dot marks the location of the upper level of KJ site where HUJI KJ 31 was found.

D. Topographic elevation of KJ site where HUJI KJ 31 was found (Green dot). E. Columnar stratigraphic section in the Kamus Junction locality.

$103 \times 58 \mathrm{~mm}(300 \times 300$ DPI $)$ 


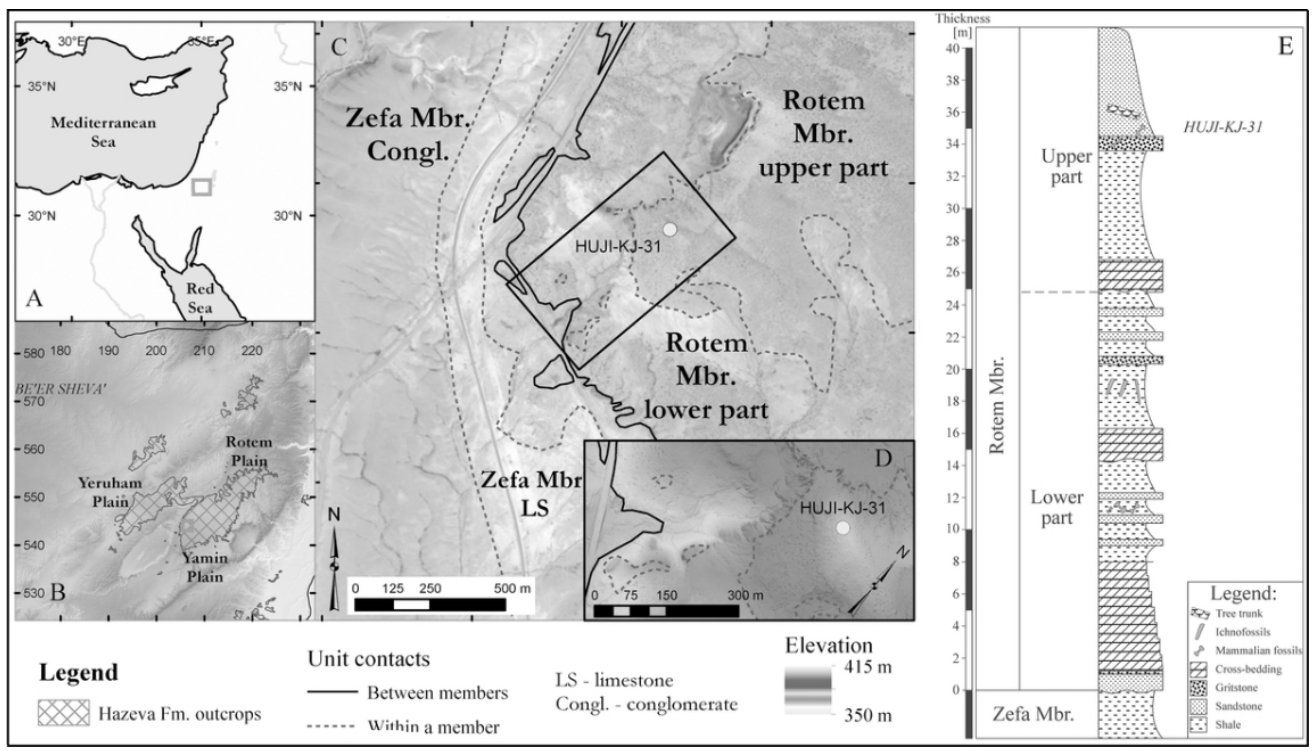

FIGURE 1. Location map of the Kamus Junction (KJ) locality in the Yamin Plain, northern Negev, Israel.

A. Genreal location of northern Negev, Israel.

B. Hazeva Formation outcrops in the northern Negev. Kamus Junction area is marked by a blue star.

C. The Hazeva Formation fills the Yamin Plain with all of its members. In the Kamus Junction area the upper parts of Zefa Member are overlain by clastic units of the Rotem Member. Small unconformity separates the lower and upper parts of the Rotem Member. Green dot marks the location of the upper level of KJ site where HUJI KJ 31 was found.

D. Topographic elevation of KJ site where HUJI KJ 31 was found (Green dot). E. Columnar stratigraphic section in the Kamus Junction locality.

$103 \times 58 \mathrm{~mm}(300 \times 300 \mathrm{DPI})$ 

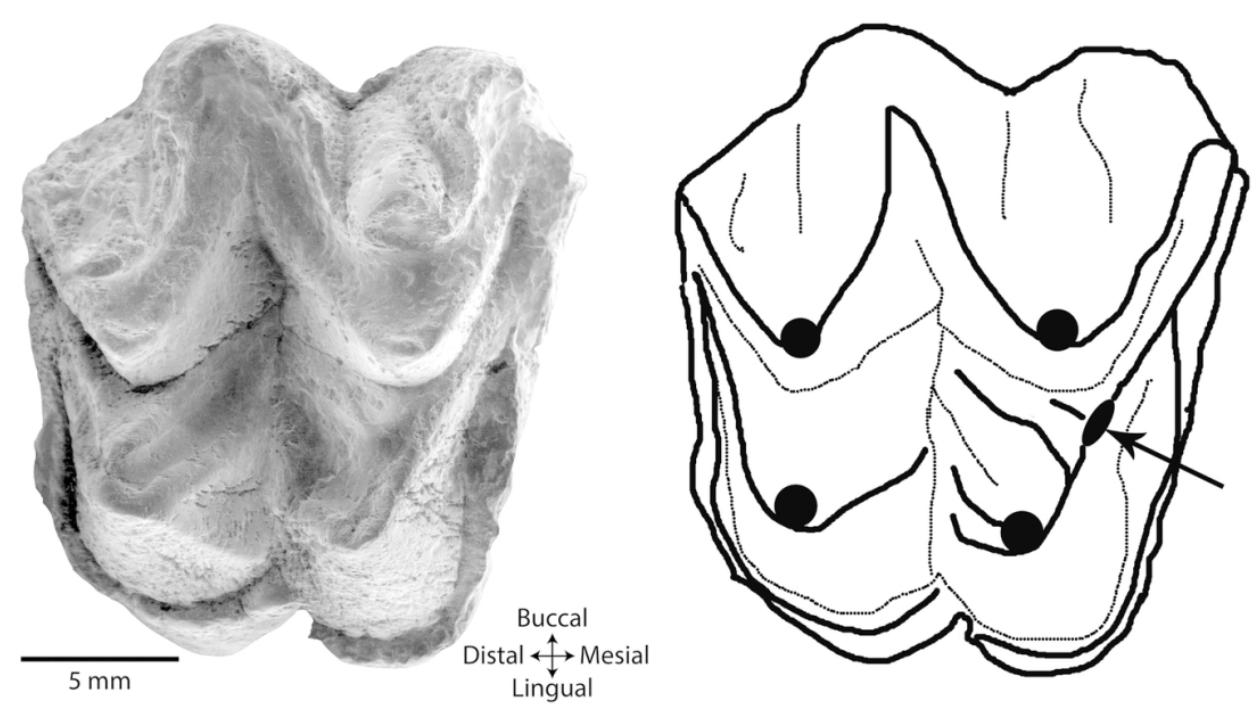

FIGURE 2. SEM and schematic drawing of HUJI KJ 31-M2 of Sivameryx palaeindicus in occlusal view. Arrow on schematic drawing indicates the paraconule.

$119 \times 64 \mathrm{~mm}(300 \times 300 \mathrm{DPI})$ 


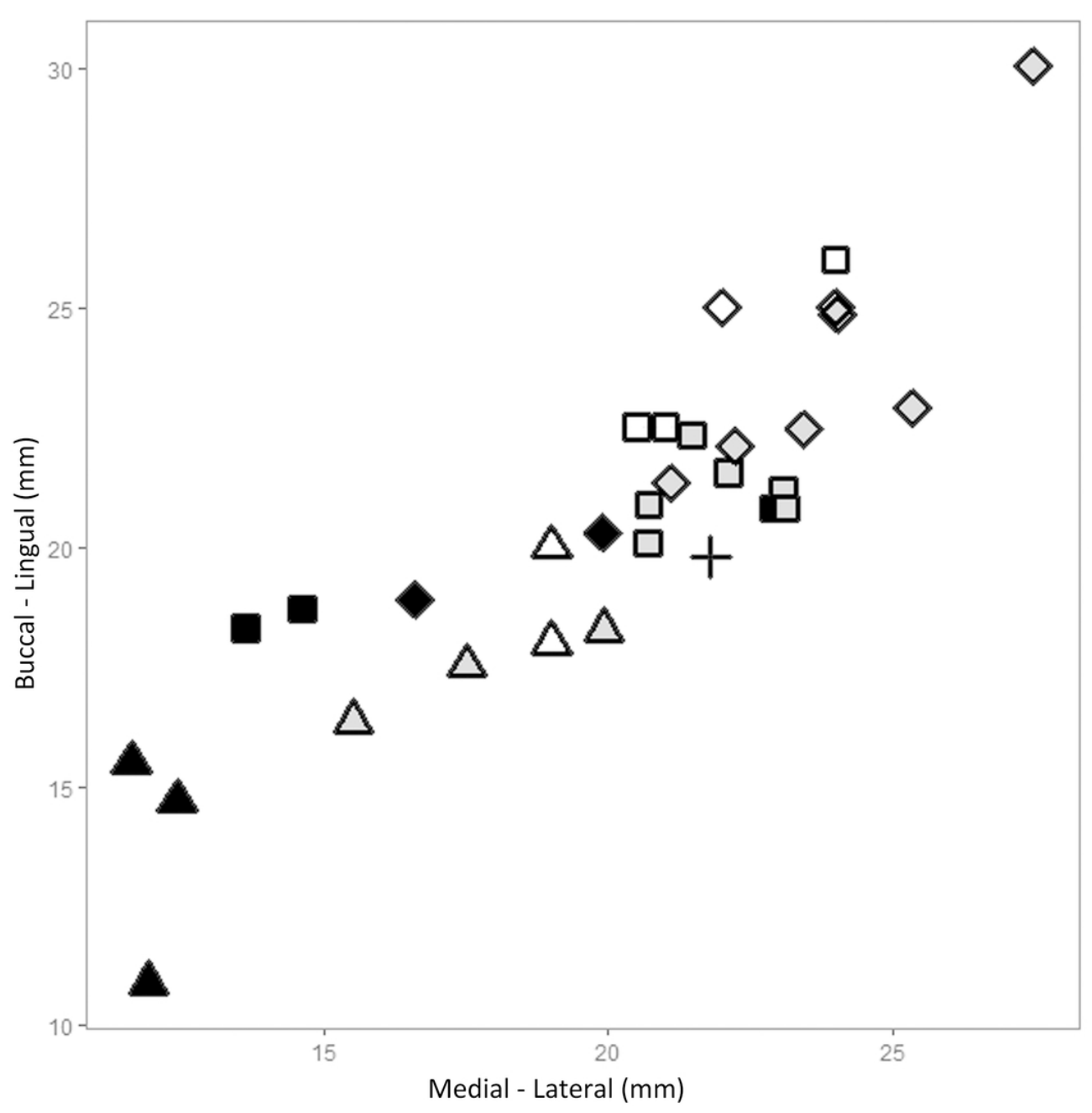

FIGURE 3. Scatter plot of upper molars of Sivameryx spp. KEY: Triangles = M1, Squares = M2, Trapezoid = M3, Cross = HUJI KJ 31 Grey fill $=S$. moneyi, Dark fill $=S$. africanus, White fill $=S$. palaeindicus Measurements listed in Table 1

$90 \times 90 \mathrm{~mm}(300 \times 300 \mathrm{DPI})$ 